Talita Tibola *

\title{
Entre besouros, vacas e garças: interagências e narrativas encantadas para a com-formação de mundos
}

Talita Tibola é psicóloga clínica e social, escritora e pesquisadora. Mestre em Educação (PPGEdu/UFRGS) pela linha de pesquisa Filosofia da Diferença e Educação, Doutora em Psicologia (PPGPsi/UFF) pela Linha de Pesquisa Subjetividade, Política e Exclusão Social. Investiga metodologias colaborativas de pesquisa e intervenção que permitem a construção de diálogo, acolhimento e acompanhamento de tomadas de decisões coletivas em ambientes clínico-sociais. Pesquisadora CAPES/ PNPD pela Escola Superior de Desenho Industrial (ESDI) da Universidade do Estado do Rio de Janeiro (UERJ), participa do Laboratório de Design e Antropologia (ESDI/ UERJ) e do grupo de pesquisa Design para a humanização da saúde pública (ESDI/ Policlínica Piquet Carneiro/UERJ). <talita.tt@gmail.com >
Resumo 0 presente artigo realiza uma reflexão sobre a noção de interagência (Despret, 2013) e como nos constituímos a nós e ao nosso mundo em agenciamento com outras espécies. Para fazer essa reflexão convocam-se as noções de forma e funcionalidade a partir de uma visão do corpo e de sistemas vivos com o intuito de constituir narrativas encantadas que possibilitem a com-formação de mundos não somente a partir de uma visão de guerra e luta entre espécies, mas espécies companheiras (Haraway, 2008). Num segundo momento, explora-se essa interagência e cocriação do mundo a partir de dispositivos de conversação, ferramenta desenvolvida pelo Laboratório de Design e Antropologia da Escola Superior de Desenho Industrial (LaDA/ESDI) e que abordo aproximando-os dos conceitos por mim desenvolvidos de escuta não pacificada e cuidado com dissenso.

Palavras chave Interagência, Forma e função, Dispositivos de conversação, Narrativas encantadas. 


\title{
Among beetles, cows and herons: inter-agency and enchanted narratives for the com-formation of worlds
}

\begin{abstract}
This paper reflects on the notion of interagency (Despret, 2013) and how we constitute ourselves and our world in agency with other species. The notions of form and functionality are called from a view of the body and living systems in order to constitute enchanted narratives that enable the formation of worlds not only from a view of war and struggle among species, but companion species (Haraway, 2008). In a second moment, this interactivity and co-creation of the world is explored from conversation dispositifs, tools developed by the Design and Anthropology Laboratory (LaDA) of the Superior School Superior of Industrial Design (ESDI) of the State University of Rio de Janeiro (UERJ). I bring these tools closer to the concepts of non-pacified listening and care with dissent developed by me.
\end{abstract}

Keywords Interagency, Form and function, Conversation dispositifs, enchanted narratives.

Entre escarabajos, vacas y garzas: interagencias y narrativas encantados para la con-formación de mundos

Resumen Este artículo reflexiona sobre la noción de interagencia (Despret, 2013) y cómo nos constituimos a nosotros y a nuestro mundo en agencia con otras especies. Para hacer esta reflexión, se convocan las nociones de forma y funcionalidad desde una mirada del cuerpo y de los sistemas vivos con el fin de constituir narrativas encantadas que posibiliten la formación de mundos no solo desde una mirada de guerra y lucha entre especies, sino de especies compañeras ( Haraway, 2008). En un segundo momento, exploro esta interagencia y co-creación del mundo a través de los dispositivos de conversación, herramientas desarrolladas por el Laboratorio de Diseño y Antropología (LaDA) de la Escuela Superior de Diseño Industrial (ESDI) de la Universidad Estadual de Río de Janeiro (UERJ). Acerco estas herramientas a los conceptos desarrollados por mí de escucha no pacificada y cuidado con disentimiento.

Palabras clave Interagencia, Forma y función, Dispositivos de conversación, Narrativas encantadas. 


\section{Introdução: o besouro e sua casca grossa}

o besouro cascudinho está na linha dos meus olhos, o vejo com sua casca característica contra o chão e as finas patas para o alto movendo-se rápida e desesperadamente. É isso o que eu vejo. Nomeio como desespero o que também percebo como sua vontade desesperada de virar-se para seguir seu caminho. Fico inerte por um tempo, por preguiça e por curiosidade. Me pergunto como ele chegou até essa posição e por qual motivo tem esse formato, uma casca tão grossa típica daqueles de sua espécie - que, segundo estudos, é o que garantiu sua heterogeneidade e sobrevivência - , mas patas tão finas incapazes de tirá-lo dessa posição. A natureza não é perfeita.

A natureza não é perfeita, ela é adaptativa, funcional. Essas duas palavras são muito delicadas de colocar em debate, a primeira por estar muito atrelada ao darwinismo social usado para justificar a eugenia e a sobrevivência do mais apto, mais forte; e a segunda por estar muito atrelada à ciência moderna e ter sido muito bem acolhida pelo pensamento capitalista e neoliberal.

William James (1842 - 1910) é considerado pai da psicologia norte-americana e influenciou diversas das suas vertentes. Por mais que tenha formulado o que ele chamou de pragmatismo é considerado fundador do funcionalismo em psicologia, movimento que, mesmo que de maneira indireta deu as ferramentas para o surgimento da psicologia enquanto ciência e técnica da adaptação "que se faz vigente até hoje de modo maciço na atualidade" (Ferreira e Gutman, 2006, p.31). Já no design, o funcionalismo expresso pela função das formas, a forma seguir a função é o seu próprio marco moderno.

Faço referência a esses dois campos, pois acredito que aqui, a maioria de meus leitores podem estar de alguma forma atrelados a eles, ao mesmo tempo gostaria de ressaltar que não pretendo dar respostas para nenhuma área específica, mas já partir de uma transversalidade entre elas. Portanto, a partir de uma conversa um pouco bagunçada com plantas, besouros e outros bichos, entre eles o que se auto-denominou humano, gostaria de me aproximar da noção de "forma" e expandir a noção do que chamamos "funcional" para pensar como nos com-formamos o tempo todo a partir de agenciamentos concretos. A bagunça, as ligações perigosas e os interlocutores escolhidos surgem de certo modo para procurar um pouco de respiração em meio a momentos tão sufocantes.

Com esse foco são convocados também autores como, Stanley Kele$\operatorname{man}^{1}$, Francisco Varela, Vinciane Despret, Donna Haraway, Deleuze e Guattari e, em referência direta ou não, colegas tanto do Laboratório de Design e Antropologia/ESDI/UERJ quanto companheiros da psicologia e de vida ${ }^{2}$. A partir desses atores pretendo lançar um outro olhar sobre essas palavras, pensar a possibilidade de algumas saúdes e como elas são atravessadas pela forma como estamos no mundo, pela forma que nos constituímos, relacio- 
namos, conversamos com ele. Como podemos criar diferentes narrativas com e através desse mundo que nos constitui e que constituímos?

Proponho assim, cinco momentos para esse debate: o primeiro e segundo para me debruçar no que estou chamando de "funcionar" a partir de uma visão do corpo e dos sistemas vivos, o segundo para desenvolver as noções de interagência que sublinha como somos inevitavelmente dependentes uns dos outros, um terceiro para pensar como podemos criar narrativas encantadas a partir do concreto que visibilizem essa interagência; e um quarto onde apresento reflexões a partir da pesquisa por mim realizada ao longo de meu pós-doutorado ${ }^{3}$. Em continuidade com os conceitos desenvolvidos em minha tese de escuta não pacificada e cuidado com dissenso, investigo a noção de dispositivos de conversação proposta por Barbara Szaniecki e Zoy Anastassakis. Dispositivos que, a partir da instigação de conversas se propõem a viabilizar a construção de narrativas encantadas que explicitem nossas interagências, codependências e busca criar novos laços e histórias.

\section{0 besouro e eu}

“A vida é forma em movimento" (Keleman, 2007, p.17), essa é uma afirmação de Stanley Keleman em seu livro Anatomia emocional. Ao perguntar porque o cascudinho é feito assim, estou me perguntando pela sua forma. Porém, não me levanto de imediato para ajudá-lo não só por preguiça, mas porque me doem as costas e me mover exigiria um bom esforço. Se eu pensar: "a natureza é perfeita", colocando-me de fora, numa divisão entre humanos e não humanos, ao olhar o besouro com as patas para cima posso me convencer de que não fazer nada nesse momento é deixar a natureza seguir seu rumo. Quem sou eu, humana, para outorgar-me o poder de ajudá-lo, salvá-lo?

No entanto, se faço parte da natureza, se me coloco com o cascudinho e penso não só na sua forma, mas também na minha, posso entrar em contato com uma consciência que não é puramente racional, mas consciência de meu corpo, que demora a levantar para desvirar o cascudinho por estar com dor. Meu corpo sabe que para levantar e desvirar o cascudinho é preciso mobilizar todo ele, esse corpo que, em sua habilidade de ser bípede, ganhou também muitas fragilidades que fazem parte de sua história e tentativa de manter-se em pé.

Keleman (2007) fala como nosso corpo é formado, e aqui podemos tomar de maneira literal, "ganha forma" a partir de sua história, a história de suas células, desenvolvimentos, acontecimentos tanto antes e depois do nascimento de um corpo. Assim, "nossa forma fica marcada pelos desafios e tensões da existência" (Ibid., p.17). Portanto, aqui estamos eu e o cascudinho numa relação em construção e se todos, humanos e não humanos, somos feitos de marcas (história) que nos atravessam e conectam, a expressão "deixar a natureza seguir seu rumo" como se estivéssemos dela separada, perde seu sentido. 
Podemos classificar Keleman como um neodarwinista por aplicar ao indivíduo e sua formação subjetivo-biológico-social o que Darwin analisou em termos de adaptação e transformação das espécies. É importante diferenciar o neodarwinismo do darwinismo social que se baseia na evolução em termos de sobrevivência do mais apto para justificar o racismo. Há uma questão importante que Keleman herda de Darwin e utiliza em sua psicologia: o fato de que a adaptação não é necessariamente otimizada, ou seja, um corpo procura se transformar com o mundo em que vive, mas nem sempre encontra uma forma que lhe faz estar melhor. Ou também, formas que antes eram funcionais, deixam de ser sem, no entanto, desaparecerem. Portanto, não existe uma forma perfeita, um ser perfeito e totalmente adaptado, uma estrutura que seja melhor que a outra, mas sim um transformar-se constante com o mundo.

Já o que diferencia Keleman de Darwin nesse caso é que essa transformação pode ser vista no processo da constituição e com-formação de um corpo (formação de um corpo com o mundo e diversos atores e situações) enquanto que para Darwin essas mudanças se dão em séculos.

À forma que vamos ganhando a partir de nossas experiências Keleman chama de "contornos emocionais" (Ibid, p.18). Assim, acontecimentos traumáticos podem levar a formas overbound ou underbound ${ }^{4}$, com contornos mais ou menos rígidos. Em algumas situações, contornos tão rígidos como se fôssemos constituídos por uma casca como a do cascudinho. Uma casca que não é necessariamente funcional em todas as situações, pois dificulta o acesso à experiência do corpo, dificulta os movimentos, mas tem uma história tem um motivo de ser. Ou seja, algo que não é mais funcional, mas que de certo modo funciona: nos impede certos movimentos, nos impede de arriscar algumas coisas, mas já é uma forma conhecida que continua nos protegendo do que sentimos como ameaça.

Para Keleman, portanto, nossas emoções são sempre corporificadas, constituem um modo concreto de ser no mundo, nesse sentido ele se aproxima de William James, que já citamos, mas também de Francisco Varela que defende uma noção corporificada e ativa da cognição humana. Segundo Varela (2003) não existe um mundo que pode ser percebido, o mundo depende do percipiente e "é a maneira pela qual o sujeito percipiente é corporificado (e não um mundo preestabelecido) que determina como o sujeito da percepção pode agir e ser modulado" (2003, p 77). O que Varela chama de cognição está ligada à capacidade de sobrevivência dos seres viventes, a forma que habitamos e nos constituímos no e com o mundo se dá a partir da criação de repertórios de diferentes micromundos que se repetem e vão nos indicando as "formas adequadas" de agir. A ação não passa por uma escolha, mas por um conhecimento corporificado, "ser capaz de ações apropriadas é (...) uma maneira pela qual damos corpos a uma torrente de transições de micromundos recorrentes" (Ibid., p.77).

Quando alguma coisa que está fora da torrente de nosso repertório acontece se dá o "colapso", um acontecimento desconhecido ao qual o ser 
vivente busca reagir criando novas respostas. "A cada colapso desses, a maneira pela qual o agente cognitivo será em seguida constituído não é nem decidida externamente nem simplesmente planejada, ao contrário, trata-se de uma questão de emergência (...) da configuração autônoma de uma postura apropriada"(Ibid., p.78). É por esse motivo que, para Varela, corpo e cognição não estão separados e a cognição não é uma apreensão de coisas, mas um processo criativo. São os próprios colapsos, no que eles ativam de reelaboração do corpo, que constituem esse lado autônomo e criativo.

o que Varela chama de colapso pode ser aproximado, mesmo que em um contexto mais localizado no humano, ao que Keleman chama de susto. Na transformação e conformação -- criação de novas formas e readaptação -- de um corpo, Keleman coloca o susto como central. Segundo ele, o susto ativa o corpo, o coloca em alarme, tendo uma primeira reação indagatória que, se recebe como resposta que a situação não é de risco, faz com que o corpo retome sua estrutura anterior, mas se tem a situação de risco confirmada e não resolvida pode levar ao estresse e desencadear diferentes reações que se expressam no corpo: autoafirmação, aborrecimento/ raiva ou abstenção, e finalmente submissão ou colapso. Para Keleman esse é como um continuum do susto, mas que não acontece necessariamente nessa ordem. Podemos ficar fixos em uma, mais de uma ou na passagem dessas formas. $\mathrm{O}$ que pode ser visto como um adoecimento, mas ao mesmo tempo a nossa forma de nos protegermos de determinada situação.

Importante destacar que Keleman e Varela denominam colapso duas situações diferentes: para Varela, o colapso é quando um sistema vivo precisa se reorganizar para criar novas respostas, já para Keleman, o colapso é uma cronificação do susto, um momento em que um corpo está com pouca responsividade depois de algum grande sofrimento. É o susto de Keleman que se aproxima do que Varela chama de colapso.

\section{Nós e nossas cascas}

A pandemia que nos assolou a todos e persiste obrigou que cada um se adaptasse à sua maneira a um novo modo de vida. Independente de um ponto de partida mais ou menos privilegiado, todos foram afetados e convocados a se reorganizar, reorganizar seus micromundos, reorganizar seus corpos. No meu caso, passei a trabalhar em casa o dia inteiro, movimentar-me menos. Quando estou diante do cascudinho pensando se me levanto ou não para desvirá-lo e percebo que não o faço por dores no corpo, a dor é um sinal de alerta que percebe que algo está errado, meu corpo não sabe ainda como se encaixar nesse mundo em que lhe são demandadas coisas diferentes (mais horas sentada, menos caminhadas e deslocamentos), mas também um caminho de adaptação a um mundo que se transforma. $O$ susto dessa pandemia pode causar diferentes ações e conformações ou até mesmo cronificações. 
Essa pandemia já encontra um mundo cronificado, de modos de vida padronizados e funcionando a favor de um sistema que nem sempre as favorece. Encontrar uma forma ajustada - que se ajuste perfeitamente ao que esse mundo nos pede - nem sempre é uma forma adequada. Como referido na introdução, James será considerado pai do funcionalismo, pois defende que a verdade de uma ideia está ligada à sua aplicabilidade, ao fato de "funcionar" ou não. Para ele, no entanto, isso fundamenta um pragmatismo onde "a ação é constituinte e não é separada de onde se dá. Acontece numa afetação entre aquele que age e o meio onde acontece a ação" (Tibola e Szaniecki, 2016, p.94). Portanto, o que para o funcionalismo seria a adaptação a um mundo pré-existente, para James é a própria constituição do mundo e do sujeito, nos constituímos com o mundo, estamos sempre sendo.

As escolas baseadas na adaptação tornam-se hegemônicas justamente porque, ao focar na positividade e individualidade, são muito bem acolhidas por processos capitalistas que continuam sendo reproduzidos até hoje, escapar desse círculo vicioso e dele conseguir captar e criar linhas de fuga não é um processo fácil, corre-se sempre o risco de uma linha de abolição (Deleuze e Guattari, 1997, p.30). Pensando com Keleman: não podemos, no cuidado de um corpo, desfazer uma forma, sem, aos poucos, dar-lhe outro contorno possível.

Se pensarmos a padronização das formas subjetivas e físicas do mundo, podemos fazer um paralelo entre as propostas de James e da Bauhaus, em que, um processo localizada e historicamente revolucionário, tendo seus princípios deslocados do contexto caem não no funcional num sentido pragmático, mas reprodutor de uma função que não é a mesma para outros mundos. Espalhar formas ditas funcionais para um mundo e corpos específicos sem pensar que essas surgiram num momento datado e a partir de relações e corpos específicos, como temos testemunhado, destrói mundos reproduzindo apenas um modo de vida padronizado. A seu tempo, o movimento da Bauhaus questionou um mundo e seus valores pré-existentes -- suas formas monárquicas que distinguiam classes -- para defender um design funcional e para todos. No entanto, não há forma que seja funcional sem o mundo onde essa forma se constitui.

\section{A vaca e a garça}

Estou no quarto no fim da tarde, a janela é voltada para o banhado onde ao fundo se avista o pôr do sol, de repente ouço uma garça cantando alto, me sinto convocada por ela, busco-a com os olhos e quando a vejo ela está ao lado de uma vaca que também a olha interessada. Ao longo dos dias percebo como a vaca e a garça andam sempre juntas, elas caminham pelo campo irregular e bastante selvagem. Há duas vacas na verdade, duas vacas e três garças inseparáveis. Fico curiosa e me contam que são chamadas de garças vaqueiras e elas andam com as vacas pois, quando esta arranca o 
pasto para comer, insetos que estavam ali parados saem de seus esconderijos de modo que a garça se alimenta deles. Dizem que andando com a vaca, a garça consegue se alimentar muito melhor do que se andasse sozinha.

Vinciane Despret em seu texto From secret agent to interagency (2013) questiona alguns etologistas contemporâneos que afirmam realizar pesquisas a partir do ponto de vista do animal para contrapor-se a um modo objetivista de fazer ciência, mas, no intuito de dar-lhes agência, esses pesquisadores acabam por subjetivá-los. Segundo a autora, portanto, o problema é que esses pesquisadores definem a agência de animais a partir de um olhar humanizado em que o agente é visto como aquele que é autônomo, independente, racional, com intenções.

Para realizar esse questionamento ela aborda trabalhos de outras pesquisadoras que retornam a Darwin analisando seu texto e relação com as plantas e animais diferenciando-o do darwinismo social que se baseou em suas ideias para justificar teorias eugênicas que criam a noção de "raças" para defender a superioridade do homem branco. Além de tirarem de contexto as afirmações de Darwin, para essas teorias o que ele chama de evolução é lido como "melhoramento", no entanto, o próprio Darwin em seu livro A origem das espécies (1985) afirma que usa a expressão luta pela existência de "maneira ampla e metafórica, incluindo nesse conceito a ideia de interdependência dos seres vivos" (Darwin, 1985, p.87). Ele dá o exemplo de que a erva de passarinho, apesar de parasita da macieira, não luta com a macieira pela existência, pelo contrário, depende dela (Ibid. p. 87). Para Darwin não há ser nem matéria que não venha de um ancestral comum, do mesmo modo não há para ele a noção da sobrevivência do "ser" mais apto, mas a manutenção de características que, mesmo surgindo na relação com o mundo podem ser transmitidas, é por isso que para ele não existe ser perfeito (Ibid., p.183), mas seres em transformação.

Eileen Crist (1999, apud Despret, 2013) mostra como Darwin admite na noção de comportamentos adequados o fato do pavão se exibir para animais de outra espécie, ou seja, esse comportamento não é útil já que a exibição não tem o intuito de incitar a reprodução, mas é um prazer exibicionista em si. Outras autoras citadas por Despret são Porcher e Schmitt, que analisam o comportamento de vacas e como elas colaboram com seus criadores facilitando a organização e antecipando ações para ajudar em seu trabalho. Segundo Despret (2013), a narrativa dessas pesquisadoras é diferente daquela que usualmente é utilizada na análise de autores que dizem partir do ponto de vista do animal, pois estes em geral vão destacar a resistência à colaboração. No ato de afirmar que resistem ao trabalho imposto pelo homem, coloca-se na vaca uma noção de agência humanizada: "elas têm opiniões, desejos, interesses" (Ibid., p. 41), por sua vez, ao observarem os momentos em que as vacas colaboram, Porcher e Schmitt não pretendem destacar capacidades intelectivas e afetivas das vacas similares às dos humanos, mas a interagência entre vacas, criador e ambiente. 
Se pensarmos a agência dos animais apenas como a escolha que fazem pela sua sobrevivência, poderíamos afirmar que os encontros da vaca e da garça que presenciei acontecem por interesse da garça em andar com a vaca para assim comer mais, ou seja, um relacionamento interessado e no qual somente a garça tem ganho. Hustak e Myers (2012) questionam esse tipo de narrativa analisando o caso de algumas orquídeas que mimetizam vespas fêmeas para atrair vespas macho para que façam sua polinização. Como a vespa macho não consegue acasalar, diz-se que a vespa não recebe nada em troca. Esse comportamento é explicado por alguns neodarwinistas a partir dos conceitos de "genes egoístas" que tem o intuito de "reduzir o gasto de energia de um organismo, maximizando sua aptidão reprodutiva para a sobrevivência da espécie a longo prazo" (Ibid., p.75). O uso desse conceito parte sempre da noção de que seres se relacionam a partir da exploração, engano, não existem nessas concepções espaço para prazer e brincadeiras entre espécies, mas sempre um modelo de economia militarizado que estrutura a vida como uma zona de guerra e de competição (Despret, 2013, p. 34). De outro modo, se pensarmos com Despret e essas pesquisadoras de que a agência não diz respeito somente a escolha e interesse, mas a interagência, podemos ver a vaca e a garça como companheiras. Usando a expressão de Haraway: vaca e garça são espécies companheiras (companion species).

Haraway (2008) fala em espécies companheiras definindo as duas palavras que a compõem a partir de seus significados etimológicos. A palavra companheiro/a é originária do latim cumpanis e carrega o significado de "compartilhar o pão", "comensais". Em inglês a palavra "comensais" é messmates, no entanto, separando a palavra que é composta por mess (bagunça) e mates (companheiro/a), ela remete a "companheiros de bagunça". Já a palavra espécie vem de specere, do latim "olhar", "guardar", "vigiar". Olhar pelo outro, fazer vigília pelo sono de outrem. Haraway a partir disso convoca a palavra re-gard do inglês e de mesma origem que tem como significados "consideração", "preocupar-se", "olhar com cuidado", mas, quando desmembrada fala mais diretamente de um "olhar de volta", "retribuir um olhar". A palavra, portanto, já implica uma coletividade, olhar e ser olhado de volta ${ }^{5}$.

Retomando então a noção de companion species, temos os companheiros de bagunça olhando uns pelos outros. Cuidando uns dos outros. A vaca e a garça são companheiras de bagunça, guardam-se umas às outras, conversam em seu sentido mais amplo e de construção de um mundo. Com-formam-se, não porque estão conformadas com um mundo pré-existente. Nem agem de maneira adequada porque tem intenções de sobreviver, mas porque esse é um mundo feito por elas, em interagência: vaca, garça, grama, insetos. 


\section{Narrativas encantadas}

Hustak e Myers (2012) quando se opõem à noção de "genes egoístas" colocam em questão uma narrativa, um modo de contar o mundo e assim, também, constituí-lo. Segundo elas, a ciência moderna no seu uso da teoria da evolução desencanta o próprio texto de Darwin. Se com este temos uma descrição cheia de detalhes - "a gama brilhante de cores, formas flexíveis, texturas sensuais e doces néctares" (Ibid., p. 76. Tradução nossa) - e maravilhada com o funcionamento da natureza, a ciência moderna usa aparelhos para captar o "rastro de atrativos químicos voláteis que a planta libera na atmosfera" (Id.). Além disso, os acontecimentos - no caso a liberação de atrativos químicos -- são sempre lidos de maneira calculista: a orquídea decepciona, engana, explora os insetos macho.

As autoras destacam que o modo de pesquisa liga-se a uma narrativa que, apesar de outorgar-se um papel objetivo e científico, constitui um discurso abstrato sobre os movimentos de plantas e animais. Da mesma forma que Varela (2003), elas propõem um reencantamento do concreto. Não precisamos de abstrações e subjetivações que sobrecodifiquem os seres e seus gestos, precisamos objetivá-los, não para tratá-los como algo sem valor, mas para poder escutá-los. Em minha tese Historias de sintonias e fronteiras: ocupar, escutar, dissentir a cidade (2014) falo que para constituir essas narrativas precisamos de uma escuta não pacificada, ou seja, uma escuta atenta que não tire a agência dos atores com quem pesquisamos, que não silencie o mundo em sua complexidade, nem disfarce as ambiguidades que se produzem em nossas relações, uma escuta que nos faça ficar com os problemas (Haraway, 2016). Para Hustak e Myers (2012, p. 78-79) constituir esse tipo de narrativa e escuta exige que, às noções evolucionistas possamos acrescentar modos "involucionários" de atenção para constituir narrativas que envolvam não apenas adaptação mas afetividade, prazer, brincadeiras, experimentação.

Uma pergunta fundamental aqui é: o que fazem as histórias que contamos? Qual mundo criam ou reproduzem? Queremos reforçar um discurso já montado sobre um mundo de competição e aplicá-lo à "natureza" descrevendo a orquídea e a garça como exploradoras ou podemos olhá-las e nos colocar em jogo também como companheiras? Como companheiras de bagunça, duas espécies em troca, em interagência, duas espécies conversando.

Deleuze e Parnet no livro Diálogos (1998) afirmam que uma conversa são "núpcias entre dois reinos (...) um devir-vespa da orquídea, um devir-orquídea da vespa" (Ibid, p.3), essa interagência e conversa entre espécies é explicada por eles a partir da noção de agenciamento, uma "unidade real mínima" que já é coletiva e que "põe em jogo, em nós e fora de nós, populações, multiplicidades, territórios, devires, afetos, acontecimentos" (Ibid., p.65). O próprio livro é uma conversa entre os autores, no entanto, num mundo acadêmico marcado pela busca da autoria da ideia, plágio, indivi- 
dualidade, muitas vezes Claire Parnet, apesar de ser uma das autoras, não é citada. É verdade que a noção de agenciamento é desenvolvida por Deleuze e Guattari (este muitas vezes não citado também ${ }^{6}$ ), mas isso não tira a co-escrita do livro Diálogos e o fato de que ele em si é um agenciamento.

A noção de agenciamento para Deleuze e Guattari se contrapõe àquela de sujeito individualizado e formado apenas pela linguagem e a partir de uma evolução filiativa $(1977 ; 1997)$. No livro Mil Platôs, capitalismo e esquizofrenia (1997) Deleuze e Guattari diferenciam o devir da evolução

\footnotetext{
devir não é uma evolução, ao menos uma evolução por dependência e filiação.(...) o devir (...) é da ordem da aliança. Se a evolução comporta verdadeiros devires, é no vasto domínio das simbioses que coloca em jogo seres de escalas e reinos inteiramente diferentes (1997, p. 16, grifo dos autores).
}

De modo parecido a Hustak e Myers (2012) que se interessam em pensar numa "involução", eles afirmam que, se o devir é uma evolução, é uma evolução "comunicativa ou contagiosa", ou melhor, "uma involucão" (Deleuze e Guattari, 1997, p.16). Involução não porque seja regressão, mas porque atém-se ao menor, se detém no entre-dois, na constituição de um agenciamento. $O$ que existe não são corpos e seres separados, mas o entre vaca-garça-grama-insetos e muitos outros seres e bactérias que não alcançamos ver. Da mesma forma, nosso corpo, como falávamos acima, se transforma, muda sua forma de acordo com suas conexões, com seu agenciamento (meu corpo-cadeira-dor, por exemplo).

Uma cadeira não é nada sem um corpo, da mesma forma sua funcionalidade não pode ser generalizada a todos os corpos, crianças, jovens, idosos, pessoas com deficiência. Se pensarmos na colonização dos povos indígenas veremos isso com mais clareza: não existem adornos, pinturas corporais de jenipapo, traçados de cipó sem um povo Kaingang que o criou e que se constitui a partir desses objetos, "o formato e as figuras geométricas dos bens artesanais identificam a família que os confeccionou, representam a cultura e a identidade kaingang e, por conseguinte, nossas metades complementares" (Claudino, 2011, p.34). Ao fazermos esse tipo de afirmação sobre um povo indígena como os Kaingang elas são facilmente acatadas por uma sociedade como a nossa constituída pelos valores da modernidade, no entanto esse tipo de afirmação não será recebida da mesma forma, se a direcionarmos a um homem branco. 0 pensamento predominante é de que o homem é constituído por sua interioridade, identidade individual e racionalidade (que, para esses mesmos valores, pode inclusive ser medida). Porém, no mundo de hoje, mesmo no mundo com valores modernos, por mais invisibilizado que isso seja, uma cadeira não é nada sem um corpo para nela sentar e um homem não é um homem sem uma cadeira. Como podemos, portanto, redesenhar o mundo, cocriar diferentes narrativas e corpos? 


\section{Entre conversas}

Em 2015, quando iniciei meu pós-doutorado no Programa de Pós-graduação em Design da Escola Superior de Desenho Industrial da UERJ e passei a colaborar com o Laboratório de Design e Antropologia (LaDA), encontrei um grupo de pesquisadoras e pesquisadores envolvidos em tentar responder essa pergunta. Uma das ações-conceito que me chamou a atenção foi o de dispositivos de conversação elaborado por Zoy Anastassakys e Barbara Szaniecki, definidos por elas de "experimentos especulativos e intervencionista de pesquisa para abrir diálogo e engajamento entre pesquisadores, estudantes e moradores de espaços urbanos" (2016, p.121). A noção de dispositivos de conversação traz a união de dois conceitos: aquele de dispositivo de Michel Foucault para fazer referência à busca da expressão de relações de força num campo heterogêneo e aquele de conversação, trazido pelas autoras a partir de Gabriel Tarde e Mikhail Bakhtin, tanto como um "construtivismo infinitesimal, sem distinção entre natureza e sociedade" (2016, p. 123) e a "constituição de nós mesmos através da palavra" (Ibid.).

A proposição desse tipo de experimento está em consonância com a ideia de, ao invés de pensar o projeto como um fim no qual somente o designer tem voz e decide o que é funcional, útil ou importante, pensá-lo como um processo que envolve diferentes atores. Vale destacar como o conceito foi desenvolvido, pois nos dá dicas de como ele pode ser usado e potencializado. A noção de conversação, por exemplo, não implica somente a criação e proposição de conversas, mas um constituir-se comum, um agenciamento; já a de dispositivo sinaliza que esses experimentos podem revelar relações de força, tensões que podem estar presentes em determinado território e podem se expressar e ser visualizadas a partir dessas conversações. Esses experimentos foram sendo utilizados por nós do laboratório em diferentes contextos: disciplinas, pesquisas, ações com alunos, criação de conversas em seminários e foi-se percebendo a sua potencialidade de tanto fazer uma espécie de cartografia de um campo/contexto ainda desconhecido quanto de viabilizar, num momento mais aprofundado da pesquisa, a fabulação coletiva de futuros possíveis (Halse et.al, 2010).

Como um bom exemplo de primeiros contatos e cartografia de um campo, podemos citar o dispositivo de conversação realizado pelos alunos Leyla Bello, Gianny Santana e Bruno Sanches na disciplina de Projeto em Design de Serviços realizado no primeiro semestre de $2019^{7}$. Na disciplina propusemos pensar projetos de serviços no bairro da Glória no Rio de Janeiro, um bairro contíguo à ESDI. Os alunos realizaram visitas para conhecer e ter uma percepção do bairro, depois de algumas observações realizaram um mapa mental e com esses dados pensaram num dispositivo de conversação que pudesse dar a eles uma percepção não só visual e unilateral, mas perceber como as pessoas viviam o bairro e quais eram as questões que 
modificariam positivamente essa vivência. Eles partiram do mapa do bairro com a pergunta: $O$ que vocês gostariam de ver na Glória? As pessoas respondiam com post its que tinham cores para diferenciar se a resposta era de um morador, trabalhador ou transeunte. As conversas que tiveram puderam dar a eles não somente um caminho possível para o projeto, mas também explicitar as tensões do bairro: os transeuntes e moradores reclamaram do cheiro de urina e fezes, os trabalhadores de rua não tem banheiros disponíveis e em geral fazem uma parceria com lojistas para suprir essa falta, já os moradores em situação de rua fazem suas necessidades nas calçadas e canteiros. A escolha dos alunos foi fazer um projeto de banheiro público colaborativo, onde as pessoas pagam um valor baixo para a sua manutenção e, quem puder, tem a opção de deixar pago para mais uma pessoa que não tem condições.

Podemos perceber que esse dispositivo de conversação não tem um lugar nem um momento pré marcado para ser realizado, ele precisa ser adaptado ao fato de que as pessoas estão ocupadas, com pressa, então, apesar de se perceber uma problemática do campo será mais difícil o aprofundamento e o debate sobre essas tensões, o que demandaria mais etapas para poder ser realizado.

Quando se trata de uma pesquisa ou acompanhamento mais prolongado, os dispositivos de conversação podem propiciar maiores debates e mais possibilidades de troca e criações coletivas. Em sua pesquisa de tese Camille Moraes (2021) aproxima design e saúde a partir do seu encontro com moradoras do bairro da Penha que frequentavam um grupo de apoio nutricional na Clínica da Família Dr. Fellipe Cardoso que estava por se desmembrar, devido à demissão da nutricionista. Ao longo de seu trabalho, os dispositivos de conversação são usados para conhecer essas mulheres, o vazio que a falta da nutricionista tinha causado e como esse conhecimento poderia ser mantido. Aos poucos, à medida que se cria uma coletividade, constituem-se narrativas não somente sobre o que se tinha perdido, mas sobre o que se poderia fazer. Nos encontros, os próprios alimentos, plantas, chás foram usados como dispositivos de conversação, e produziam um nutrir com ligado tanto ao alimento quanto ao cuidado. Em um desses encontros, a partir de um dispositivo de conversação que tinha como questão disparadora "O que é saúde?" desenvolveu-se uma conversa sobre moradia, violência, racismo, dificuldade dos moradores nas decisões públicas e o assassinato de Marielle Franco (Moraes, 2021, p.144).

Meu interesse por essa metodologia se deu por serem "espaço de diálogo e discussão entre perspectivas heterogêneas" (Tibola et. al,2017, p. 73), por viabilizarem um "constituir-se com", visibilizarem nossa interagência e desse modo colocarem em questão proximidades e tensões. Em minha tese, desenvolvo a noção de cuidado com dissenso, ali discuto a importância de podermos discordar uns dos outros, sem invisibilizar essas diferenças, nesse sentido a importância de uma escuta não pacificada para não silenciar uma ou outra posição e destacar a heterogeneidade do que se 
constitui numa conversação. Os dispositivos de conversação podem proporcionar situações em que tanto o propositor da atividade quanto os participantes são deslocados de sua zona de conforto. Quando um pesquisador, um designer, um psicólogo, arquiteto ou outro profissional convoca uma atividade, muitas vezes espera-se que ele dê respostas. Porém, um dispositivo de conversação estará funcionando no momento que essa centralidade possa ser tirada ou, pelo menos, diminuída.

É necessário aqui sublinhar que quando afirmo que os dispositivos de conversação viabilizam um "constituir-se com", não significa que estamos todos separados em nossa individualidade e essa ferramenta metodológica criará uma interagência ou agenciamento. 0 dispositivo de conversação está mais para uma ferramenta com potencial de realizar o deslocamento de um agenciamento a outro, o entre-dois onde algo pode ser criado. Quando se chega em qualquer campo, já existem agenciamentos dados, agenciamentos esses que podem ser muito potentes, mas podem também estar desorganizados ou presos a determinados modos de funcionamento. Um dispositivo de conversação, busca portanto, reconhecer esses funcionamentos de um grupo ou comunidade e viabilizar que possam pensar juntos e/ou transformar seus modos de agir. A partir de "conversas contagiantes" criar caminhos (im)possíveis e narrativas encantadas.

Uma situação em que os próprios dispositivos de conversação podem criar um agenciamento é quando eles agem sobre um grupo ainda não constituído. Esse foi o caso do curso "Contingente necessário: entre criação e cuidado" no Centro Municipal de Arte Hélio Oiticica - RJ que realizei em 2019 com Gabriel Alvarenga. O curso propunha metodologias, vivências e modos coletivos de acompanhamento de processos com o foco de refletir sobre o que de nosso contingente não podemos ou não queremos abrir mão. Como fica claro pelo objetivo, era um curso bastante aberto e recebemos pessoas inscritas, cada uma com seu percurso e suas histórias. Um grupo de pessoas ainda não é um agenciamento. No entanto, ao longo da realização do curso foram sendo realizadas atividades que colocavam os participantes em contato com seu próprio corpo, seus diferentes mundos, materiais e questões para, aos poucos explorar as contingências de cada um. A partir do olhar do outro, do contato e das atividades foram se percebendo e constituindo desencantos e desejos coletivos e cada encontro ia constituindo um possível para cada um.

Um dispositivo de conversação que nos acompanhou ao longo de todo o curso foi um tecido de filó que ficava pendurado na sala com a pergunta: 0 que se passa entre... ? Das atividades de cada dia as pessoas escolhiam o que gostariam de deixar marcado, o que achavam importante destacar e deixar colado ou costurado no filó para constituir um discurso sobre o percurso coletivo. Eram feitas também conexões entre os materiais que se coletavam. 
Em um de nossos encontros foi utilizado também o Jogo dos verbetes, jogo que foi desenvolvido pelo LaDA e foi se transformando a cada novo uso $^{8}$. No curso Contingente necessário foram colocadas cartas hexagonais na mesa com frases provocativas e frases dos próprios participantes que eu e Gabriel havíamos coletado ao longo do curso, depois de visualizar as cartas, cada um escolheu três delas. As outras foram retiradas da mesa e foi colocada a carta com escrito "Contingente necessário". As instruções foram de cada um falar, a partir das cartas que havia escolhido, qual era seu contingente -- sua situação presente -- e o que considerava como necessário em sua vida. A primeira pessoa começou a falar espontaneamente e depois a roda seguia à esquerda dessa pessoa. Havia duas outras cartas que podiam ser usadas: "treta", quando alguém queria contrapor-se ou complementar o que estava sendo dito pela pessoa e "textão" para pedir que a pessoa passasse a palavra pois estava monopolizando a fala. Essa última carta precisava ser aceita por todo o grupo. Ao longo da conversa foi-se delineando o que cada um valorizava e queria priorizar em sua vida, compartilharam-se angústias sobre trabalhos, debateu-se sobre política criando uma possibilidade de valorização do presente, do contingente de cada um e que acaba por ser seu continente. No caso desse curso, em que não havia a perspectiva de um projeto de design ou tomada de decisão coletiva, o dispositivo de conversação funcionou como ferramenta de contato clínico que, a partir da visualização de questões pode ir criando e desfazendo nós em direção a narrativas compartilhadas. 


\section{Considerações finais}

A experiência desse curso me vem à memória agora, um momento de contingências tão difíceis e em que o que cada um tem de continente parece desmoronar. Lembro dele num curto momento, entre o último mês de um ano pandêmico, trancada num apartamento vendo a morte chegar ao meu redor, e os primeiros meses de um ano que começa ainda incerto 9 . Vivemos um momento em que o que fizeram de Darwin continua a imperar, defende-se despudoradamente uma falsa "seleção natural", a sobrevivência dos mais fortes, dos imunes, dos jovens, daqueles sem comorbidades, daqueles que desfilam sua gorda saúde dominante (Deleuze, 1997, p.14). quando a comorbidade que potencializa as mortes é a desigualdade social atravessada pelo racismo, pelo feminicídio, capacitismo.

Contam-se as mortes, elas são ignoradas e se esquece da vida no que ela tem de mais singular e coletivo. Não temos resposta sobre como criar narrativas possíveis, sobre como reencantar o concreto, pois nossa casca ou está muito dura ou nossas patas muito finas, colapsadas. Se não temos respostas, só podemos multiplicar as perguntas. Como constituir juntos um mundo onde a colaboração e um andar junto desinteressado e não somente a guerra sejam possíveis? Como criar narrativas encantadas no mundo em que vivemos, sem pacificá-lo ou nos alienarmos?

Reconhecer nossa interagência não só entre humanos, mas também entre espécies companheiras não é defender um mundo de guerra e luta pela sobrevivência, tampouco nos iludirmos de que essa interagência seja sempre pacífica. Estamos em contato e interagência com um vírus que transforma nossos mundos e modos de maneira radical e nos força a encontrarmos outras formas de vida.

Estamos procurando nos conformar no meio de um susto cronificado, mas para poder não só sobreviver é preciso a todo momento lembrar que não nos conformamos, mas nos com-formamos. Será a partir de um concreto ainda incerto, mas do que se tem de mais próprio ou próximo, de um contingente, que poderemos criar novos continentes e novas formas que sejam funcionais, ou seja, que dêem potência ao nosso corpo e aos mundos que constituímos.

Por fim, levantei e desvirei o cascudinho, o que durou poucos segundos: ele logo caiu com as patas para cima. Realizei a mesma ação repetidamente e não adiantou, ele sempre dava alguns passos e uma de suas patas falhava e o levava a ficar com as patas para cima. À noite estávamos eu e a família de Daniel, meu companheiro, no pátio, ali ficam sempre dois sapos, cada um em sua posição preferida. Ana, minha sogra, os chama de seus companheirinhos, os sapos comem muitos cascudinhos e outros insetos. Ana deixa alguns potes de água que ela limpa na manhã seguinte, onde eles vão se hidratar e defecar de madrugada. No fim da noite, antes de dormir, Josi, minha cunhada começa a rir, pois o sapo havia defecado, saía de dentro deles muitos cascudinhos, alguns deles, vivos por causa de sua casca grossa difícil de digerir. 
1 Apesar de não citada diretamente aqui, minha leitura de Keleman é profundamente influenciada pela leitura de Regina Favre em seu Laboratório de Processo Formativo (https://laboratoriodoprocessoformativo.com) 2 Deste último campo destaco Raphaella Daros e Gabriel Alvarenga enquanto psicólogos, pesquisadores e amigos que junto com Daniel Stringini, etnomusicólogo e compositor, meu companheiro, pudemos constituir um modo de viver e compor juntos, nos observar no/com nossos mundos ao longo dessa pandemia em curso.

3 Pós doutorado realizado com o apoio do Programa Nacional de Pós Doutorado (PNPD) da Capes

4 No Brasil utilizam-se as expressões em inglês para manter a sua polissemia (limite, fronteira, contorno). Em espanhol usa-se "extralimitados" e "infralimitados". Essa tradução mantém a noção de limite, um corpo que é mais ou menos aberto para se deixar invadir. Outra possível tradução seria extra e infra-delimitado, ressaltando assim a ideia de contorno: um corpo com mais ou menos contorno.

5 Já abordei a questão das espécies companheiras nos artigos Cuidado com dissenso: pensando mobilizações político-artísticas no Rio de Janeiro a partir de uma ética-prática do cuidado publicado na revista Pesquisas e Práticas Psicossociais 11 (1), São João del Rei, Janeiro a junho de 2016; e Pequenos destinos: caminhos para uma clínica no presente a partir de um sonho pandêmico a ser publicado no livro "Corpos em quarentena" pela Edufes.

6 Abordo essa exclusão de Guattari das referências de seus livros com Deleuze no artigo Agenciamento, território e transversalização: como olhar a crise publicada na Revista LUGAR COMUM , v. 3, p. 80-95, 2018.

7 Realizei essa disciplina junto com as professoras convidadas Mariana Costard e Liana Ventura. Participou dela também Camille Moraes na realização de seu estágio discente. A criação da disciplina tinha como intuito explorar metodologias participativas e foi participativa também em sua criação.

80 jogo, em sua primeira versão, tinha um funcionamento muito simples: 1) distribuem-se cartas em forma de hexágono onde estão impressas palavras, frases e imagens que se relacionam com a temática que se quer discutir, 2) a seguir os participantes escolhem umas dessas cartas, 3) então ao centro será colocada uma carta com uma questão disparadora e, 4) sem ordem pré-definida, as pessoas relacionam suas cartas com a questão central ou com as cartas dos outros participantes. Após essa primeira versão,o dispositivo foi sendo transformado conforme a situação e o intuito do que queria provocar. Em alguns usos as cartas foram distribuídas aleatoriamente para instigar as pessoas a pensarem a partir de algo mais desconhecido, foram adicionadas cartas extras como "treta" e "textão" para criar um debate que pudesse colocar em jogo o dissenso e também distribuísse a fala, além de em outros momentos as cartas mudarem de formato e ser criada uma dinâmica em que elas eram penduradas em fios que iam se cruzando, dando mais dinâmica e convocando o corpo ao jogo.

9 Esse texto está sendo escrito entre o final do ano de 2020 e o início de 2021 ao longo da Pandemia ligada ao Coronavírus que tomou grande proporção mundial devido à rápida transmissibilidade desse tipo de vírus e suas variantes. Instalou-se desse modo um caos sanitário devido à falta de leitos e insumos hospitalares. A frase em questão faz referência irônica a uma trecho da música Ouro de tolo de Raul Seixas, pois para conter o alastramento do vírus foram indicadas pela Organização Mundial da Saúde (OMS) algumas medidas preventivas: afastamento social como quarentena, ficar e trabalhar desde casa quando possível, evitar e não produzir aglomerações, fechamento temporário de serviços não essenciais e utilização de máscaras e distanciamento social em locais públicos. No Brasil, a proporção da Pandemia foi ainda maior pelo fato do governo não adotar e ridicularizar essas medidas, questionar a gravidade do vírus e indicar medicamentos sem comprovação científica como tratamento preventivo. No momento, após pouco mais de um ano de pandemia, foram mais de 358 mil mortos somente por Covid com uma média de mortes diárias de quase 4 mil pessoas. 


\section{Referências}

ANASTASSAKIS, Z; SZANIECKi, B. Conversation Dispositifs: Towards a Transdisciplinary Design Anthropological Approach. SMITH, Rachel Charlotte et. al. (orgs). Design Anthropological Futures.London: Bloomsbury, 2016, p. 121-138.

BIZ, P.; COSTA, D.; THEMOTEO, P.; SOARES, F.; SZANIECKI, B. e ANASTASSAKIS, Z. Design micelial. Uma proposta para agricultura urbana a partir dos projetos do Laboratório Espaços Verdes da ESDI-UERJ. Lugar Comum: Estudos de mídia, cultura e democracia. Universidade Nômade, n. 53, mai.-dez. 2018.

CLAUDINO, Z. K. As narrativas Kaingangs nas aldeias. Objetos-sujeito: a arte kaingang como materialização de relações. Org.:Luiz Fernando Caldas Fagundes João Mauricio Farias. FUNAI, 2011.

DARWIN, C. A origem das espécies. Tradução: Eugênio Amado. Editoria Itatiaia, Belo Horizonte; EDUSP, São Paulo, 1985

DELEUZE, G. Crítica e clínica. Tradução: Peter Pál Pelbart. Editora 34, São Paulo, 1977.

DELEUZE, G; GUATTARI, F. Kafka: por uma literatura menor. Tradução: Julio Castañon Guimarães. Imago Editora, Rio de Janeiro, 1977.

DELEUZE, G; GUATTARI, F. Mil platôs: capitalismo e esquizofrenia. Vol.4. Tradução Suely Rolnik. Editora 34, São Paulo, 1997.

DELEUZE, G.; PARNET, C. Diálogos. Tradução: Eloísa Araújo Ribeiro. Escuta, São Paulo, 1998. DESPRET, V. From secret agent to interagency. History and Theory. Theme Issue, 52 (December, 2013). 29-44 Wesleyan University.

FERREIRA, A. A. L; GUTMAN, G. o funcionalismo em seus primórdios: a psicologia a seriço da adaptação Jacó Vilela, A. M.;:; Portugal, F.T. História da psicologia: rumos e percursos. Rio de Janeiro: Nau Ed., 2006.

HALSE, J., BRANDT, E., CLARK, B. and BindER, T. Rehearsing the Future. Copenhagen: The Danish Design School Press, 2010.

HARAWAY, D. Staying with the trouble: making kin in the Chthulucene. Duke University Press, 2016.

HARAWAY, D. When species meet. University of Minnesota Press, Minnesota/London, 2008. HUSTAK, C.; MYERS, N. Involutionary Momentum: Affective Ecologies and the Sciences of Plant/Insect Encounters. Différences 23, no. 3 (2012), 74-118.

KELEMAN, S. Anatomía emocional: la estructura de la experiencia somática.6.edición. Tradução: Juan González Llagostera. Desclée de Brower, Bilbao, 2007.

MORAES, C. "Nutrir com": uma experiência degustativa sobre Design \& Saúde. (Tese). Universidade do Estado do Rio de Janeiro, 2021.

TIBOLA, T.; Biz, P.; SZANIECKI, B.; SERPA, B.; SECIOSO, F.; VENTURA, L. Regras, trapaças e a poética do comum: reflexões a partir do design colaborativo de dispositivos de conversação. Anais do $7^{\circ}$ Simpósio Imagem e Identidade e Território. E agora América Latina?: práticas insurgentes no mosaico territorial. Porto Alegre, Faculdade de Arquitetura da UFRGS, 2017. TIBOLA, T. e SZANIECKI, B. Pragmatismo do disforme no design. Revista Trágica: estudos de filosofia da imanência, Rio de Janeiro, v.9 no 3, p. 86-95, 2016

VARELA, F. $O$ reencantamento do concreto. Cadernos de subjetividade n.11, PUC - São Paulo, 2003.

Recebido: 15 de fevereiro de 2021 .

Aprovado: 05 de março de 2021. 